\title{
Persepsi Pengunjung Tentang Objek Wisata Di Taman Wisata Alam Sorong Provinsi Papua Barat
}

\author{
Maya Pattiwael $^{1}$; Yetty Siska Serkadifat ${ }^{2}$ \\ Universitas Victory Sorong, Indonesia \\ ${ }^{1}$ mayapattiwael@yahoo.com
}

\begin{abstract}
Abstrak
Suatu kawasan yang dijadikan sebagai tempat wisata tentu harus memiliki daya tarik tersendiri yang unik dan berbeda dengan kawasan wisata lainnya. TWA Sorong merupakan salah satu kawasan wisata yang masih terus dikembangkan untuk menarik minat wisatawan atau pengunjung untuk datang ke tempat tersebut. Peningkatan jumlah pengunjung di suatu lokasi juga tidak terlepas dari kepuasan pengunjung itu sendiri terhadap daerah yang dikunjungi. Pemilihan responden sebagai sampel penelitian dilakukan dengan metode Accidental Sampling. Sampel dalam penelitian ini adalah sebanyak 67 orang. Pengumpulan data pada penelitian ini dilakukan dengan studi kepustakaan, observasi langsung di lapangan, serta pembagian kuesioner kepada pengunjung objek wisata di Taman Wisata Alam Sorong. Persepsi pengunjung tentang objek wisata di Taman Wisata Alam Sorong memberikan hasil yang positif untuk 4 indikator yaitu daya tarik (skor rata-rata 285,2 dengan kategori sangat baik), aksesibilitas (Skor rata-rata 260, kategori baik), fasilitas (Skor rata-rata 264,9 kategori baik) dan layanan tambahan (Skor rata-rata 241,5 dengan kategori baik) . Beberapa harapan yang disampaikan oleh responden terkait pengembangan lokasi tersebut ke depan yaitu berupa perbaikan fasilitas yang ada seperti penambahan tempat sampah dan adanya kebersihan toilet.
\end{abstract}

Kata kunci : Persepsi pengunjung, objek wisata, Taman Wisata Alam

\section{PENDAHULUAN}

Pengertian Taman Wisata Alam (TWA) seperti yang tercantum dalam Undangundang Republik Indonesia Nomor 5 tahun 1990 Tentang Konservasi Sumber Daya Alam Hayati dan Ekosistemnya adalah kawasan pelestarian alam yang terutama dimanfaatkan untuk pariwisata dan rekreasi alam. Dalam kawasan tersebut dapat dilakukan kegiatan yang berhubungan dengan penelitian, ilmu pengetahuan, pendidikan, menunjang budidaya, budaya dan wisata alam dengan tetap mengacu pada aturan yang telah ditetapkan. Penunjukan TWA sebagai kawasan pariwisata dan rekreasi alam memberi peluang bagi masyarakat untuk dapat berekreasi dan menikmati pemandangan alam dalam kawasan tersebut.

Suatu kawasan yang dijadikan sebagai tempat wisata tentu harus memiliki daya tarik tersendiri yang unik dan berbeda dengan kawasan wisata lainnya. Menurut Undang-undang Republik Indonesia Nomor 10 Tahun 2009 tentang Kepariwisataan, yang dimaksudkan dengan wisata adalah kegiatan perjalanan yang dilakukan oleh seseorang atau sekelompok orang dengan mengunjungi tempat tertentu untuk tujuan rekreasi, pengembangan pribadi, atau mempelajari keunikan daya tarik wisata yang 


\section{Median Volume 12 Nomor 1 Bulan Februari 2020}

Doi http://doi.org/md.v12i1.151

dikunjungi dalam jangka waktu sementara. Lebih lanjut disebutkan bahwa daya tarik wisata adalah segala sesuatu yang memiliki keunikan, keindahan, dan nilai yang berupa keanekaragaman kekayaan alam, budaya, dan hasil buatan manusia yang menjadi sasaran atau tujuan kunjungan wisatawan.

TWA Sorong merupakan salah satu kawasan wisata yang masih terus dikembangkan untuk menarik minat wisatawan atau pengunjung untuk datang ke tempat tersebut. Kawasan ini dekat dengan aktivitas perkotaan karena berada di tengah kota sehingga dikatakan merupakan "paru-paru" kota Sorong. Disamping itu, kawasan ini juga berbatasan dengan jalan utama, sehingga mudah untuk dijangkau. Walaupun belum banyak masyarakat yang mengetahui tentang objek wisata yang menarik dalam kawasan TWA Sorong, namun tempat ini cukup sering dikunjungi, baik dari dalam Kota Sorong, luar daerah bahkan dari mancanegara.

Pengelolaan kawasan TWA Sorong dilakukan oleh Unit Pelaksana Teknis Balai Besar Konservasi Sumber daya Alam (KSDA) Provinsi Papua Barat. Berdasarkan SK penunjukkan kawasan hutan oleh Menteri Pertanian Indonesia Nomor 397/Kpts/Um/5/1981, luas kawasan TWA Sorong adalah sebesar 945,9 hektar, yang memiliki ekosistem hutan dataran rendah yang masih terjaga, dihuni berbagai jenis tumbuhan dan satwa, memiliki daerah tangkapan air, dan terdapat hutan tanaman Damar (Agathis labilardieri) dan Araucaria spp.

Menurut Balai Besar KSDA Papua Barat, dalam kawasan TWA Sorong terdapat sekitar 53 jenis vegetasi berkayu seperti Matoa, Merbau, Medang, Angsana, Lansat, Cempedak, Rambutan, dan lain-lain. Adanya tumbuhan dan satwa yang beanekaragam, camping ground, bird watching, air terjun dan beberapa potensi wisata lainnya menjadikan TWA Sorong sebagai salah satu pilihan tujuan wisata. Keberadaan potensi wisata tersebut tentu didukung oleh ketersediaan fasilitas lainnya seperti tempat parkir, tempat sampah, shelter, tower pengamatan satwa, toilet dan akses wisata seperti jalan masuk, penunjuk arah dan jalan setapak.

Pengembangan TWA Sorong sebagai objek destinasi wisata ke depan dilakukan dengan tujuan untuk mendorong peningkatan daya tarik wisatawan domestik dan mancanegara (BBKSDA Papua Barat, 2018). Salah satu faktor penentu keberlanjutan kegiatan wisata adalah secara ekologis berkelanjutan, artinya pembangunan pariwisata tidak menimbulkan efek negatif bagi ekosistem setempat. Dengan demikian, aspek konservasi seharusnya tidak dilupakan, karena konservasi merupakan kebutuhan yang harus diupayakan untuk melindungi sumberdaya alam dan lingkungan dari efek negatif kegiatan wisata (Arida, 2017).

Selama tahun 2018, pengunjung yang melakukan kunjungan ke TWA Sorong adalah sebanyak 309 orang (BBKSDA Papua Barat, 2019). Jumlah tersebut tentu saja masih sangat rendah, namun dengan adanya pengembangan kawasan TWA Sorong dan pengelolaan yang baik maka diharapkan jumlah pengunjung di lokasi tersebut semakin meningkat di tahun-tahun berikutnya. Dukungan berbagai pihak tentu saja sangat dibutuhkan untuk dapat bekerjasama dan berkontribusi dalam pengembangan kawasan 


\section{Median Volume 12 Nomor 1 Bulan Februari 2020}

Doi http://doi.org/md.v12i1.151

ini. Peningkatan jumlah pengunjung di suatu lokasi juga tidak terlepas dari kepuasan pengunjung itu sendiri terhadap daerah yang dikunjungi, baik tentang daya tarik, aksesibilitas, fasilitas maupun pelayanan yang diperoleh. Hal ini tentu saja berdampak bagi pengembangannya ke depan. Oleh karena itu, perlu dilakukan penelitian mengenai persepsi pengunjung tentang objek wisata di Taman Wisata Alam (TWA) Sorong Provinsi Papua Barat".

Penelitian ini diharapkan dapat memberi manfaat yaitu sebagai sumber informasi bagi instansi terkait untuk terus melakukan perbaikan, pengembangan dan pengelolaan yang baik terhadap TWA Sorong sebagai objek destinasi wisata.

\section{METODE PENELITIAN}

Pemilihan responden sebagai sampel penelitian dilakukan dengan metode Accidental Sampling. Menurut Sugiyono (2007), Accidental Sampling merupakan teknik penentuan sampel secara kebetulan, yaitu siapa saja yang secara kebetulan bertemu dengan peneliti dapat digunakan sebagai sampel, bila dipandang orang yang kebetulan ditemui itu cocok sebagai sumber data. Sampel dalam penelitian ini adalah sebanyak 67 orang.

Pengumpulan data pada penelitian ini dilakukan dengan studi kepustakaan, observasi langsung di lapangan, serta pembagian kuesioner kepada pengunjung objek wisata di Taman Wisata Alam Sorong. Kuesioner yang dibagikan merupakan kuesioner berstruktur (pernyataan tertutup) dan didasarkan pada Skala Likert. Responden diminta menentukan jawabannya pada setiap pernyataan dengan memilih sesuai skor pada Skala Likert (Tabel 1.)

Tabel 1. Kriteria Pemberian Skor Skala Likert

\begin{tabular}{cc}
\hline Alternatif Jawaban & Skor \\
\hline Sangat setuju (SS) & 5 \\
Setuju (S) & 4 \\
Cukup setuju (CS) & 3 \\
Kurang setuju (KS) & 2 \\
Tidak setuju (TS) & 1 \\
\hline
\end{tabular}

Sumber : Sugiyono, 2007

Data yang diperoleh kemudian diolah menggunakan rumus rata-rata ideal (Mi) dan standar deviasi (Sdi). Arikunto (2010) mengklasifikasikannya ke dalam 5 kategori, yaitu:

1. Kategori sangat baik: $\geq(\mathrm{Mi}+1,5 \mathrm{Sdi})$

2. Kategori baik: $(\mathrm{Mi}+0.5 \mathrm{Sdi})-<(\mathrm{Mi}+1.5 \mathrm{Sdi})$

3. Kategori cukup baik: $(\mathrm{Mi}-0.5 \mathrm{Sdi})-<(\mathrm{Mi}+0.5 \mathrm{Sdi})$

4. Kategori kurang baik: $(\mathrm{Mi}-1,5 \mathrm{Sdi})-<(\mathrm{Mi}-0.5 \mathrm{Sdi})$

5. Kategori tidak baik: < $(\mathrm{Mi}-1,5 \mathrm{Sdi})$ 
Untuk mencari skor rata-rata ideal (Mi) dan standar deviasi (Sdi) digunakan rumus:

$\mathrm{Mi}=1 / 2($ Nilai ideal maksimum + Nilai ideal minimum $)$

Sdi $=1 / 6$ (Nilai ideal maksimum - Nilai ideal minimum)

Data yang telah diolah selanjutnya dianalisis secara deskriptif.

\section{HASIL DAN PEMBAHASAN}

\section{Karakteristik Responden}

1. Responden Berdasarkan Jenis kelamin

Data pada Tabel 2. Menunjukan bahwa responden yang berjenis kelamin wanita lebih dominan daripada pria. Responden jenis kelamin pria sebanyak 28 responden $(41,79 \%)$, dan wanita sebanyak 39 responden $(58,21 \%)$.

Tabel 2. Responden Berdasarkan Jenis Kelamin

\begin{tabular}{cccc}
\hline No. & Jenis Kelamin & Jumlah Responden & Persentase $(\%)$ \\
\hline 1 & Pria & 28 & 41,79 \\
2 & Wanita & 39 & 58,21 \\
\hline & Total & 67 & 100
\end{tabular}

Sumber: Data Primer, 2019

2. Responden Berdasarkan Usia

Berdasarkan usia, responden yang berkunjung ke objek wisata TWA Sorong sangat beragam. Pada Tabel 3. menunjukan bahwa responden yang berada pada usia 1720 tahun sebanyak 18 orang (26,87\%), usia 21-30 tahun sebanyak 28 orang (41,79\%), usia 31-40 tahun sebanyak 14 orang $(20,89 \%)$, dan usia $\geq 41$ tahun sebanyak 7 orang $(10,45 \%)$.

Tabel 3. Responden Berdasarkan Usia

\begin{tabular}{cccc}
\hline No. & Usia (Tahun) & Jumlah Responden & Persentase $(\%)$ \\
\hline 1 & $17-20$ & 18 & 26,87 \\
2 & $21-30$ & 28 & 41,79 \\
3 & $31-40$ & 14 & 20,89 \\
4 & $\geq 41$ & 7 & 10,45 \\
\hline & Total & 67 & 100
\end{tabular}

Sumber : Data primer, 2019

3. Responden Berdasarkan Tingkat Pendidikan Terakhir

Berdasarkan Tabel 4. Diketahui bahwa pengunjung Taman Wisata Alam yaitu sebanyak 3 orang $(4,48 \%)$ memiliki pendidikan terakhir SMP, 27 orang $(40,3 \%)$ memiliki pendidikan terakhir SMA, 10 orang $(14,92 \%)$ memiliki pendidikan terakhir D3, sebanyak 22 orang $(32,84 \%)$ memiliki pendidikan terakhir S1, dan pendidikan 
terakhir S2 sebanyak 5 orang $(7,46 \%)$. Dengan demikian responden dengan tingkat pendidikan terakhir SMA adalah yang paling dominan.

Tabel 4. Responden Berdasarkan Tingkat Pendidikan

\begin{tabular}{cccc}
\hline No & Pendidikan Terakhir & Jumlah Responden & Persentase (\%) \\
\hline 1 & SMP & 3 & 4,48 \\
2 & SMA & 27 & 40,3 \\
3 & D3 & 10 & 14,92 \\
4 & S1 & 22 & 32,84 \\
5 & S2 & 5 & 7,46 \\
\hline & Total & 67 & 100
\end{tabular}

Sumber: Data Primer, 2019

4. Responden berdasarkan pekerjaan

Berdasarkan Tabel 5, pengunjung yang dijadikan sebagai responden yang berkunjung ke Taman Wisata Alam memiliki pekerjaan PNS/Guru sebanyak 13 orang $(19,41 \%)$, karyawan swasta 21 orang $(31,34 \%)$, nelayan 1 orang $(1,49 \%)$, wiraswasta 9 orang $(13,43 \%)$ dan 23 orang $(34,33 \%)$ adalah mahasiswa.

Tabel 5. Responden Berdasarkan Pekerjaan

\begin{tabular}{cccc}
\hline No. & Jenis Pekerjaan & Jumlah Responden & Persentase (\%) \\
\hline 1 & PNS/Guru & 13 & 19,41 \\
2 & Swasta & 21 & 31,34 \\
3 & Nelayan & 1 & 1,49 \\
4 & Wiraswasta & 9 & 13,43 \\
5 & Mahasiswa & 23 & 34,33 \\
\hline & Total & 67 & 100
\end{tabular}

Sumber: Data primer, 2019

Pengunjung berdasarkan pekerjaan yang paling dominan adalah mahasiswa dan karyawan swasta. Para mahasiswa pada umumnya memiliki motivasi berwisata karena adanya rasa ingin tahu yang tinggi terhadap objek yang dikunjungi. Sementara itu, responden lain yang sudah memiliki pekerjaan tetap, mereka sering melakukan perjalanan wisata untuk menghindari rasa bosan dari pekerjaan yang setiap hari dilakukan, sehingga kegiatan wisata biasanya dilakukan untuk refreshing dan memulihkan kembali semangat kerja.

5. Sumber informasi tentang objek wisata TWA Sorong

Berdasarkan Tabel 6, bahwa sebanyak 59 responden mengetahui informasi objek wisata dari teman atau saudara yang sudah lebih dulu mengunjungi objek wisata di TWA Sorong, terutama informasi tentang perkembangan pengelolaan objek wisata di Tempat tersebut, sehingga setiap orang yang mendengarnya menjadi tertarik untuk mengunjungi lokasi yang ada. 
Tabel 6. Sumber Informasi Objek Wisata

\begin{tabular}{cccc}
\hline No. & Informasi Objek Wisata & Jumlah Responden & Persesntase (\%) \\
\hline 1 & Media cetak & 3 & 4,48 \\
2 & Media elektronik & 4 & 5,97 \\
3 & Teman/saudara & 59 & 88,06 \\
4 & Biro perjalanan wisata & 1 & 1,49 \\
\hline & Total & 67 & 100
\end{tabular}

Sumber: data primer, 2019

\section{Persepsi pengunjung tentang Objek Wisata di TWA Sorong}

Sebanyak 67 orang pengunjung yang menjadi responden dalam penelitian ini, mengisi setiap lembar kuisioner dengan sangat baik. Keseriusan, ketelitian dan kejujuran dalam mengisi kuisioner tentu saja mempengaruhi hasil akhir dari suatu penelitian. Kuisioner yang diberikan terdiri dari 4 indikator, yaitu daya tarik, aksesibilitas, fasilitas/sarana prasarana, layanan tambahan.

Tabel 7. Persepsi Pengunjung Tentang Daya Tarik TWA Sorong

\begin{tabular}{clcc}
\hline No. & Parameter & Skor & Kategori \\
\hline 1. & Pemandangan alam & 286 & Sangat Baik \\
2. & Kesejukan udara & 312 & Sangat Baik \\
3. & Tumbuh-tumbuhan & 289 & Sangat Baik \\
4. & Hewan/Satwa & 261 & Baik \\
5. & Air terjun & 278 & Sangat Baik \\
\hline & Rata-rata & 285,2 & Sangat Baik \\
\hline
\end{tabular}

Sumber : Data diolah, 2019

Berdasarkan Tabel 7 dapat dilihat bahwa skor rata-rata persepsi pengunjung tentang daya tarik TWA Sorong sebesar 285,2 dengan kategori sangat baik. Responden mengaku sangat menikmati pemandangan alam dan kesejukan udara yang ada di TWA Sorong. Pemandangan dan kesejukan udara yang ada dalam kawasan tidak bisa ditemukan di luar kawasan. Berbagai jenis burung, hijaunya pohon-pohon dan menariknya berbagai potensi objek wisata yang ditemukan dalam kawasan membuat responden benar-benar menikmati suasana yang ada. Menurut responden kesejukan udara yang dirasakan membuat mereka dapat menghirup udara segar. Iklim dan kondisi lingkungan yang ada dalam hutan sangat berbeda dengan di luar hutan. Begitu banyak pohon-pohon di dalam hutan mampu melakukan proses fotosintesis yang menyerap Karbondioksida $\left(\mathrm{CO}_{2}\right)$ dan melepaskan Oksigen $\left(\mathrm{O}_{2}\right)$ sehingga kita dapat menghirup dan merasakan kesejukan udara segar di dalam hutan. 


\section{Median Volume 12 Nomor 1 Bulan Februari 2020}

Doi http://doi.org/md.v12i1.151

Tabel 8. Persepsi Pengunjung Terhadap Kondisi Aksesibilitas di TWA Sorong

\begin{tabular}{clcc}
\hline No. & \multicolumn{1}{c}{ Parameter } & Skor & Kategori \\
\hline 1. & Jalan masuk & 264 & Baik \\
2. & Penunjuk arah & 226 & Baik \\
3. & Jalan setapak & 290 & Sangat Baik \\
\hline & Rata-rata & 260 & Baik \\
\hline
\end{tabular}

Sumber: Data diolah, 2019

Hasil pada Tabel 8 menunjukkan bahwa rata-rata skor untuk akses di TWA Sorong adalah 260 dan termasuk kategori baik. Menurut responden, jalan yang dilalui pada saat masuk kawasan tidak begitu baik, namun karena pengelolaan objek wisata TWA Sorong masih dalam tahap pengembangan sehingga kondisi jalan saat ini masih dapat dimengerti. Responden menyarankan agar pihak pengelola membatasi setiap kendaraan seperti truk yang masuk dan keluar kawasan karena justru kendaraan seperti itu yang menyebabkan kerusakan jalan. Sementara itu kondisi jalan setapak terlihat sangat baik. Hal ini dapat dilihat pada Gambar 1. Papan penunjuk arah dapat ditemukan dalam lokasi sehingga memudahkan pengunjung untuk menemukan tempat yang dituju. Penelitian lain yang dilakukan oleh Purwanto, Sadjati, dan Insusanty (2019) tentang persepsi pengunjung terhadap daya tarik wisata Danau Tajwid Kecamatan Langgam Kabupaten Pelalawan menunjukan bahwa papan penunjuk arah di sekitar lokasi Danau Tajwid masih sedikit (skor 267 dan kategori cukup baik) sehingga tentunya pengunjung merasa kesulitan.

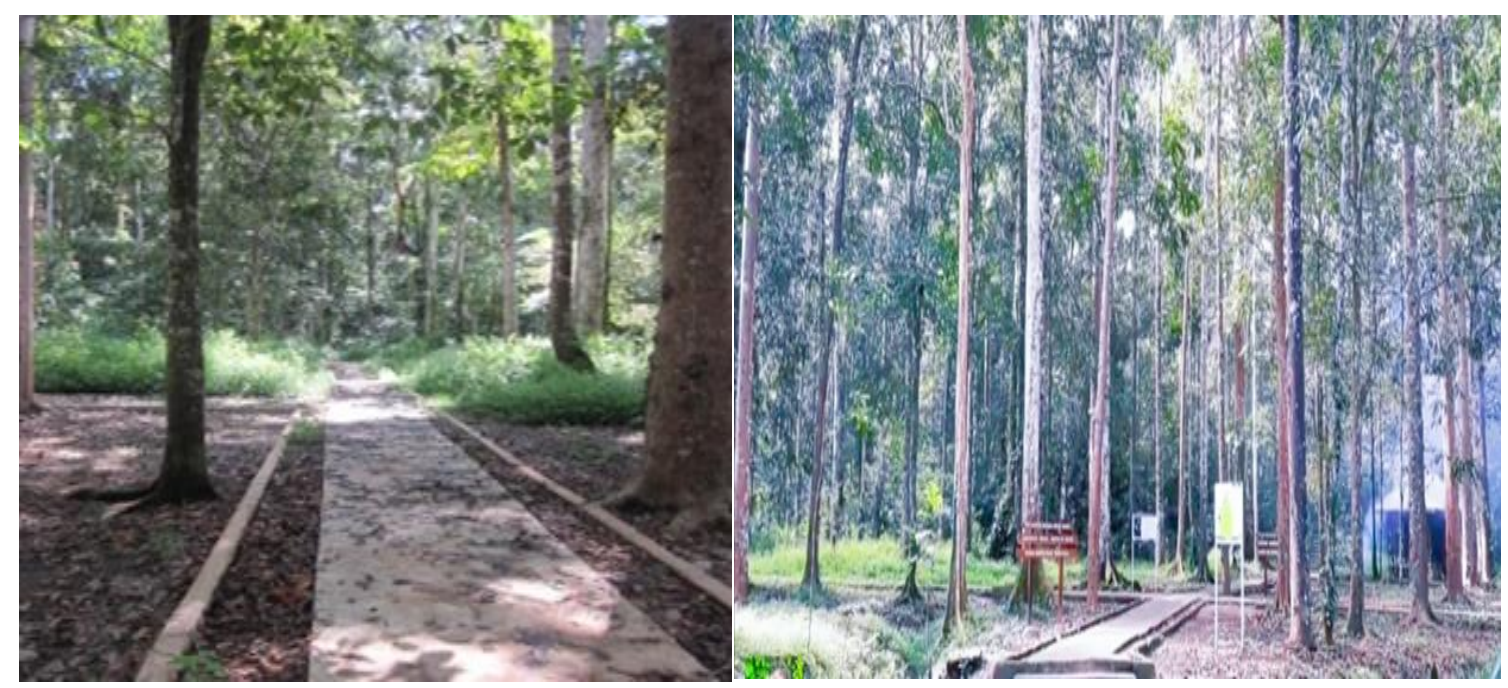

Gambar 1. Kondisi Jalan Setapak Dalam kawasan TWA Sorong 


\section{Median Volume 12 Nomor 1 Bulan Februari 2020}

Doi http://doi.org/md.v12i1.151

Tabel 9. Persepsi Pengunjung Tentang Fasilitas/Sarana Prasarana di TWA Sorong

\begin{tabular}{clcc}
\hline No. & \multicolumn{1}{c}{ Parameter } & Skor & Kategori \\
\hline 1. & Pos resort & 291 & Sangat Baik \\
2. & Tower pemantauan suara burung & 309 & Sangat Baik \\
3. & Tempat parkir & 263 & Baik \\
4. & Tempat sampah & 208 & Cukup Baik \\
5. & Shelter & 248 & Baik \\
6. & Toilet & 241 & Baik \\
7. & Papan nama tumbuhan dan satwa & 286 & Sangat Baik \\
8. & Papan tanda larangan & 273 & Sangat Baik \\
\hline & Rata-rata & 264,9 & Baik
\end{tabular}

Sumber: Data diolah, 2019

TWA Sorong menyediakan beberapa fasilitas pendukung yang dapat digunakan oleh para pengunjung seperti yang disajikan pada Tabel 9.Ketersediaan tempat sampah mendapat skor yang sangat rendah yaitu 208 dengan kategori cukup baik. Hal ini disebabkan karena tempat sampah yang ada di TWA Sorong masih sedikit jumlahnya dan sulit ditemukan, sehingga pengunjung kesulitan ketika membuang sampah. Hal tersebut tentu berpengaruh pada kebersihan di lokasi objek wisata TWA Sorong. Walaupun di beberapa sudut jalan menuju objek wisata sudah ada papan tanda larangan, namun tidak menutup kemungkinan pengunjung membuang sampah sembarangan jika tidak menemukan tempat sampah. Responden bahkan menginginkan adanya penambahan tempat sampah di sekitar lokasi objek wisata.

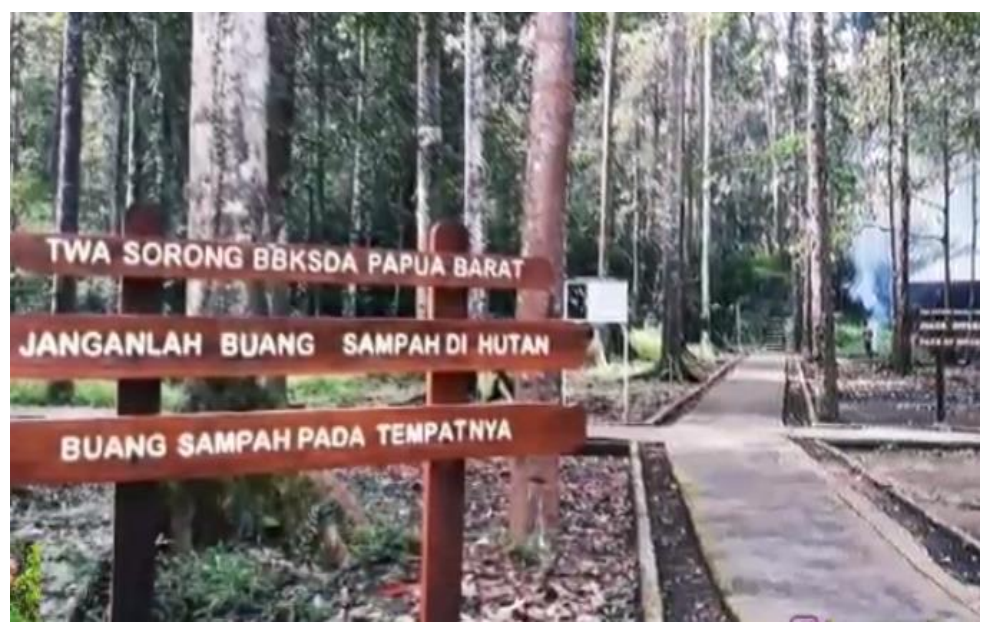

Gambar 2. Papan Tanda Larangan di TWA Sorong

Tempat parkir kendaraan dinilai memiliki kondisi yang baik dan memadai, artinya setiap pengunjung yang datang bisa mendapatkan tempat parkir untuk kendaraannya. Namun jika pengunjung yang datang dalam jumlah yang banyak maka diperkirakan 


\section{Median Volume 12 Nomor 1 Bulan Februari 2020}

Doi http://doi.org/md.v12i1.151

akan kesulitan mencari tempat parkir. Oleh karena itu dalam proses pengembangan TWA Sorong diharapkan adanya penambahan lahan parkir.

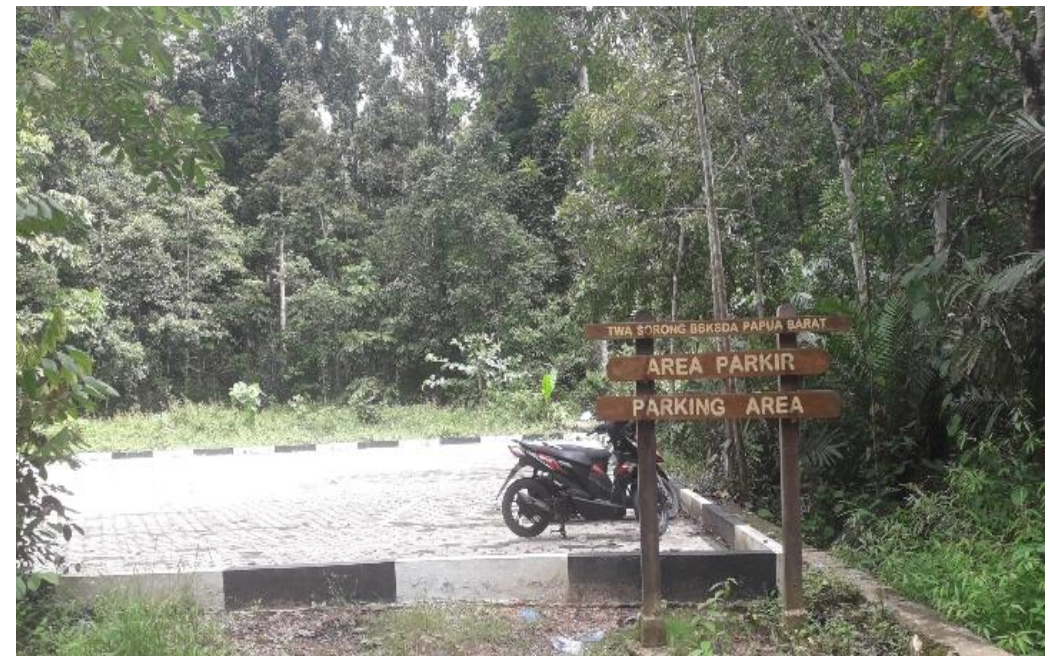

Gambar 3. Tempat Parkir Kendaraan di TWA Sorong

Fasilitas berupa toilet memang disediakan bagi pengunjung namun jumlahnya sangat terbatas dan menurut responden toilet juga tidak mudah ditemukan. Salah satu penyebabnya adalah tidak adanya penunjuk arah atau jalan menuju tempat tersebut sehingga pengunjung juga merasa kesulitan. Selain itu kebersihan toilet juga masih dibawah standar sehingga pengunjung merasa kurang nyaman untuk menggunakan toilet. Secara keseluruhan persepsi pengunjung tentang fasilitas/sarana prasarana di TWA Sorong termasuk dalam kategori baik dengan rata-rata skor 264,9.

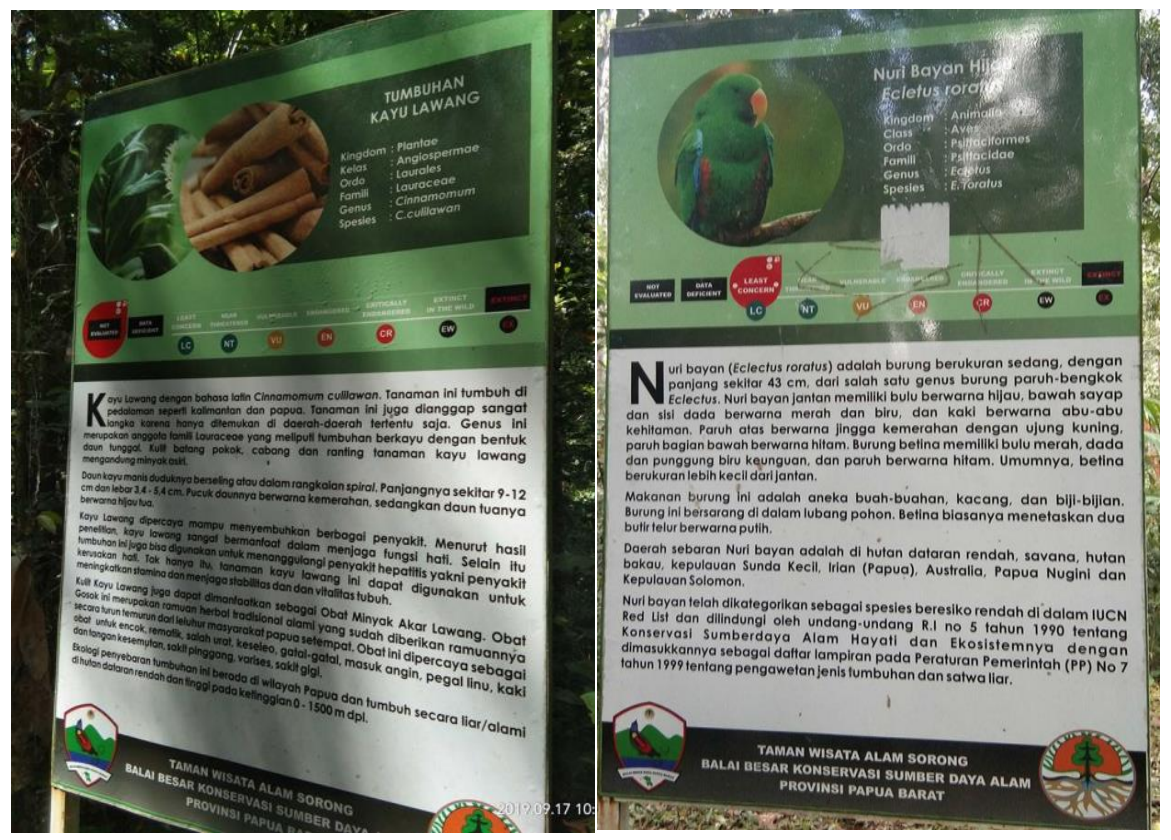

Gambar 4. Papan Nama Tumbuhan dan Satwa 


\section{Median Volume 12 Nomor 1 Bulan Februari}

Doi http://doi.org/md.v12i1.151

Tabel 10. Persepsi Pengunjung Tentang Layanan Tambahan di TWA Sorong

\begin{tabular}{clcc}
\hline No. & \multicolumn{1}{c}{ Parameter } & Skor & Kategori \\
\hline 1. & Penetapan harga tiket masuk & 230 & Baik \\
2. & Kelayakan & 261 & Baik \\
3. & Kenyamanan & 246 & Baik \\
4. & Keamanan & 233 & Baik \\
5. & Pelayanan dari petugas di TWA & 226 & Baik \\
6. & Pengelolaan objek wisata & 253 & Baik \\
\hline & & 241,5 & Baik
\end{tabular}

Sumber: Data diolah, 2019

Di dalam kuisioner pengunjung juga diminta untuk memberikan tanggapan tentang kelayakan, kenyamanan, keamanan dan pelayanan yang diterima pada saat mengunjungi dan berada dalam TWA Sorong. Berdasarkan hasil penelitian, responden menyatakan bahwa TWA Sorong merupakan tempat yang layak dikunjungi. Kelayakan ini dilihat dari potensi objek wisata yang dapat dinikmati dan menarik bagi pengunjung.

Kenyamanan untuk mengunjungi suatu lokasi tentu harus didukung oleh keamanan tempat tersebut. Sebagian besar pengunjung merasa nyaman dan keamanan di TWA Sorong juga dirasakan terjamin. Namun ada beberapa diantara mereka juga memberikan tanggapan sebaliknya. Hal ini disebabkan karena setiap pengunjung yang masuk ke TWA Sorong dibiarkan masuk secara bebas tanpa adanya penagihan karcis atau pemeriksaan identitas lainnya, sehingga kemungkinan adanya tindakan dari orang yang tidak bertanggung jawab bisa saja terjadi.
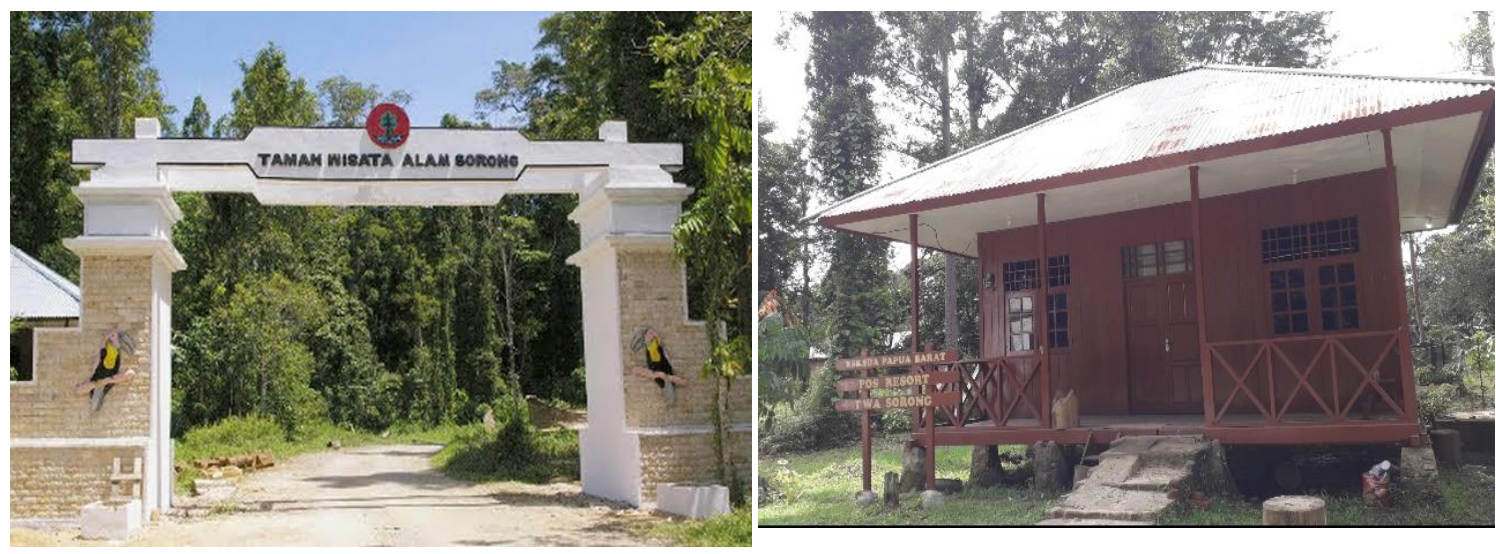

Gambar 5. Pintu masuk dan Pos Resort Taman Wisata Alam Sorong

Penetapan harga tiket masuk mendapat tanggapan yang baik dari responden. Menurut mereka tiket masuk dapat mengontrol setiap pengunjung yang datang. Selain itu, hasil dari penagihan harga tiket juga dapat digunakan untuk pengelolaan objek wisata agar lebih baik lagi. Namun responden berharap bahwa harga tiket masuk yang ditetapkan harus bisa terjangkau oleh masyarakat. Bagi responden yang sudah sering 


\section{Median Volume 12 Nomor 1 Bulan Februari 2020}

Doi http://doi.org/md.v12i1.151

mengunjungi TWA Sorong, menganggap bahwa pengelolaan objek wisata di lokasi tersebut sudah semakin baik dibandingkan tahun-tahun sebelumnya. Namun pengelolaan yang baik itu perlu terus ditingkatkan agar dapat menarik minat pengunjung untuk datang ke kawasan itu. Ketersediaan fasilitas dalam suatu objek wisata merupakan bagian yang tidak terpisahkan. Oleh karena itu perhatian terhadap perbaikan dan kelengkapan fasilitas harus dilakukan.

Kepuasan pengunjung terhadap suatu lokasi yang dikunjungi juga sangat dipengaruhi oleh pelayanan yang diberikan oleh pihak pengelola atau petugas di lokasi tersebut. Kurangnya petugas atau SDM yang mendampingi pengunjung ke lokasi objek wisata sehingga mereka merasa kesulitan untuk mendapatkan informasi yang mereka inginkan. Hal ini dapat dibuktikan pada Tabel 10 yang menunjukan skor untuk pelayanan petugas yang paling rendah yaitu sebesar 226. Meskipun demikian pelayanan petugas masih tergolong kategori baik. Secara umum rata-rata skor pada Tabel 10 sebesar 241,5 dan masuk kategori baik.

\section{KESIMPULAN}

Persepsi pengunjung tentang objek wisata di Taman Wisata Alam Sorong yang dilihat dari 4 indikator, yaitu daya tarik, aksesibilitas, fasilitas/sarana prasarana, dan layanan tambahan pada umumnya bersifat positif. Persepsi tentang daya tarik TWA Sorong dengan 5 parameter mendapat skor rata-rata sebesar 285,2 dengan kategori sangat baik. Persepsi terhadap kondisi aksesibilitas dengan 3 parameter mendapat ratarata skor sebesar 260 dan termasuk kategori baik. Sementara itu, persepsi tentang fasilitas/ sarana prasarana dengan 8 parameter dan layanan tambahan dengan 6 parameter, masing-masing mendapat skor rata-rata sebesar 264,9 dan 241,5 dan termasuk kategori baik.

Adanya pengembangan TWA Sorong ke depan sebagai destinasi wisata merupakan harapan dari para responden. Oleh sebab itu, perbaikan terhadap fasilitas yang ada perlu mendapat perhatian seperti penambahan tempat sampah di sekitar lokasi objek wisata, kebersihan toilet, bahkan pemeriksaan identitas dari pengunjung agar tingkat keamanan lebih terjamin.

\section{DAFTAR PUSTAKA}

Arida S I Nyoman. 2017. Ekowisata: Pengembangan, Partisipasi Lokal, dan Tantangan Ekowisata. Cakra Press. Denpasar. Bali.

Arikunto, S. 2010. Prosedur Penelitian Suatu Pendekatan Praktik. Jakarta: Rineka Cipta

BBKSDA PB. 2018. BBKSDA Papua Barat Ajak Stakeholder Tarik Wisatawan Mancanegara ke TWA Sorong. Kementerian lingkungan Hidup dan Kehutanan https://bbksda-papuabarat.com tanggal akses 12-11-2019 


\section{Median Volume 12 Nomor 1 Bulan Februari 2020}

Doi http://doi.org/md.v12i1.151

Fentri D. M. 2017. Persepsi Pengunjung Terhadap Daya Tarik Wisata Alam Hutan

Rimbo Tujuh Danau Di Desa Wisata Buluh Cina Kecamatan Siak Hulu Kabupaten Kampar Riau. JOM FISIP Vol 4 No. 2 Oktober 2017

Purwanto, Emy Sadjati, dan Enny Insusanty. 2019. Persepsi Pengunjung Terhadap Daya

Tarik Wisata Danau tajwid Kecamatan Langgam Kabupaten Pelalawan. Wahana Forestra : Jurnal Kehutanan Vol. 14 No. 1 Januari 2019

Sugiyono. 2007. Metode Penelitian Kuantitatif, Kualitatif dan R\&D. Alfabeta. Bandung 